\title{
Legal Principle of Authentication Power of Authentic Deed Becomes Private Deed Due to Age Limit for Notary Appearers
}

\author{
Natasha Meydia Essiva \\ Student of Notary Magister Program of Faculty of Law Universitas Jember \\ Aries Harianto \\ Doctor and Lecturer of Postgraduate Program of Faculty of Law Universitas Jember \\ Ermanto Fahamsyah \\ Doctor and Lecturer of Postgraduate Program of Faculty of Law Universitas Jember
}

\begin{abstract}
Besides having to obey the Law on Notary Position and the Code of Ethics, a Notary must pay attention to certain principles, one of which is the Precautionary Principle. This Principle is an important factor in knowing the appearers attending the Notary Office. To avoid mistakes and errors in making the deeds, the Notary must be able to acknowledge the appearers. In addition, the Notary should read the deed in front of the parties, so that the parties signing and witnessing the birth of the deed are fully aware of every point stated by the deed and its legal consequences. Furthermore, other significant matter that the notary must also pay attention to is the age of the attending parties. Article 39 paragraph (1) of the Act on Office of Notary Public states that a person who appears before the Notary to make a deed should meet the requirements of the minimum age 18 (eighteen) years or married. (2) The appearers must be recognized by the Notary or introduced to him by 2 (two) knowing witnesses attaining the minimum age of 18 (eighteen) years or married, and is capable of taking legal actions or is introduced by other 2 (two) appearers. Article 40 states: Every deed read out by a notary is attended by at least 2 (two) witnesses, unless the statutory regulations stipulate otherwise. Witnesses as referred to in paragraph (1) shall meet the following requirements: a. attaining the minimum age of 18 (eighteen) years or married; $b$. being capable of doing legal actions; c. understanding the language used in the deed; $d$. being able to affix signature and initials; and e. mot having marriage relations in upper or lower straight line without any degree limitation and until the third degree with the Notary Public or parties.Referring to Article 39 of the Act on Office of Notary Public regarding the minimum age of appearers, philosophically is also related to the legal age limit. In fact, several laws and regulations in Indonesia show the differences between one another in determining the adult age limit. The Civil Code considers that adults boundary is at the age of 21 (twenty one) years, Article 47 paragraph (1) of the Law on Marriage states 18 (eighteen) years, and Act on Office of Notary Public is at least 18 (eighteen) years old. It certainly affects the legal certainty of the adult age limit. If the appearer is still under 18 (eighteen) years of age, then the deed that will be made by the notary will become underhanded deed, while the position of the deed is weak and does not have legal certainty.
\end{abstract}

Keywords: Age limit, authentic deed, legal certainty, notary public, private deed

DOI: $10.7176 / \mathrm{JLPG} / 105-08$

Publication date: January $31^{\text {st }} 2021$

\section{INTRODUCTION}

Based on the 1945 Constitution of the Republic of Indonesia Article 1 paragraph (3) Indonesia is a constitutional state (rechstaat). This provision implies that, first, Indonesia is a State of law (Rechsstaat), which is not merely based on power (Machstaat); second, the government is based on a constitutional system (basic law), or is not absolutism (unlimited power). It means that the dynamics of law in Indonesia shall refer to legal ideals oriented towards the aspects of certainty, expediency and justice. ${ }^{1}$ This ideals include the regulations that underlie the duties of a notary as a public official. ${ }^{2}$ Notary is a social institution known as a "notariat", arising from the needs of the community who require evidence regarding the existing civil law relationships among them. Notaries are assigned by the general power (openbaar gezag) to make written evidence having an authentic power, where the law requires and the community wants. ${ }^{3}$ Thus, the position of notary is born due to the needs of the community.

The word "notary" derives from the word "nota literaria" which means a written sign or character used to write or describe sentences conveyed by a resource person. The sign or character in a sign used in shorthand (stenographie). This notary who became a royal writer had a position as a palace employee, which is not in accordance with the position of a notary today. Notaries also exist in the papal powers called "tabellio" and

\footnotetext{
${ }^{1}$ Marwan Effendy Kejaksaan Republik Indonesia, Posisi dan Fungsinya dari Perspektif Hukum,(Jakarta: PT. Gramedia Pustaka Utama, 2005), p. 151

${ }^{2}$ Penggunaan kata "pejabat umume mengacu pada buku Habib Adjie, Hukum Notaris Indonesia, (Bandung : Refika Aditama, 2008),p16

${ }^{3}$ G.H.S. Lumban Tobing, Peraturan Jabatan Notaris, Erlangga, Jakarta, 1982, p. 2.
} 
"clericus notarius publics" which provide assistance on civil law relations. ${ }^{1}$ At the beginning of the birth of the notary office, it was clear that the nature of being a public official (private notary) was assigned by the general power to serve the needs of the community for authentic evidence that provides certainty of civil law relations. Thus, as long as authentic evidence is still required by the country's legal system, the existence of the notary is still needed by the community. ${ }^{2}$ Notary is a public official who has the duty and obligation to provide legal services and consultations to the public. Legal assistance that can be provided by a notary is in the form of making written evidence that has authentic power, namely in the form of authentic deeds or other authorities as referred to in the law. ${ }^{3}$

Notaries shall provide legal advice in accordance with the existing problems. Any legal advice given by the notary public to the parties and put it into the deed, it remains as the wishes or statements of the parties concerned, and it is not a statement of the notary. ${ }^{4}$ Article 16 of the Act Number 2 of 2014 on the Position of Notary paragraph (1) letter (a) in carrying out his position, notaries are obliged to act trustworthy, honestly, thoroughly, independently, not taking sides and protecting the interests of the parties involved in legal actions. The meaning of "thorough" in this article can be interpreted as being careful in carrying out the task as well as in getting to know the appearers. In carrying out a legal action, a notary shall always act carefully by examining all relevant facts in his consideration based on the prevailing laws and regulations. Checking all the completeness and validity of evidence or documents shown to the notary and hearing the statements of the parties shall be done as a basis for consideration to be stated in the deed. ${ }^{5}$ In performing the duties, a Notary must be professional, namely prioritizing the expertise based on code of ethics and the provisions of the applicable laws and regulations, having trustworthy performance, upholding the applicable legal rules, performing and producing accurate results. Furthermore, notaries shall be able to provide appropriate and good legal counseling for the parties.

The aspects of a notary's authority cannot be applied beyond what has been determined in the applicable regulations. It means the notary shall not take advantage of his authority for other purposes other than those specified in the applicable regulations or to use the authority that exceeds its limit. A notary deed must provide certainty that the events and facts mentioned in the deed were actually carried out by the notary or explained by the appearers in accordance with the procedures stipulated in the deed drafting. Formally, to prove the truth and certainty of the day, date, month, year, and hour (time), the appearers, initials and signatures of the parties/ appearers, witnesses and notaries, as well as proving what was seen, witnessed, heard by a Notary (on the official $\mathrm{deed} / \mathrm{minutes}$ ), and recording information or statements of the parties/ appearers (on the deed of parties). ${ }^{6}$

In addition to having to obey the Law on Notary Public and the Code of Ethics, a Notary must pay attention to certain principles, one of which is the Precautionary Principle. This Principle is an important factor in knowing the appearers attending the Notary Office. To avoid mistakes and errors in making the deeds, the Notary must be able to acknowledge the appearers. In addition, the Notary should read the deed in front of the parties, so that the parties signing and witnessing the birth of the deed are fully aware of every point stated by the deed and its legal consequences. ${ }^{7}$ Furthermore, other significant matter that the notary must also pay attention to is the age of the attending parties. Article 39 paragraph (1) of the Act on Office of Notary Public states that a person who appears before the Notary to make a deed should meet the requirements of the minimum age 18 (eighteen) years or married. (2) The appearers must be recognized by the Notary or introduced to him by 2 (two) knowing witnesses attaining the minimum age of 18 (eighteen) years or married, and is capable of taking legal actions or is introduced by other 2 (two) appearers. Article 40 states: Every deed read out by a notary is attended by at least 2 (two) witnesses, unless the statutory regulations stipulate otherwise. Witnesses as referred to in paragraph (1) shall meet the following requirements: a. attaining the minimum age of 18 (eighteen) years or married; $b$. being capable of doing legal actions; c. understanding the language used in the deed; d. being able to affix signature and initials; and e. mot having marriage relations in upper or lower straight line without any degree limitation and until the third degree with the Notary Public or parties. ${ }^{8}$

In regards to Article 39 of the Act on Office of Notary Public regarding the minimum age of appearers, philosophically is also related to the legal age limit. In fact, several laws and regulations in Indonesia show the differences between one another in determining the adult age limit. The Civil Code considers that adults boundary is at the age of 21 (twenty one) years, Article 47 paragraph (1) of the Law on Marriage states 18 (eighteen) years, and Act on Office of Notary Public is at least 18 (eighteen) years old. It certainly affects the legal certainty of the

\footnotetext{
${ }^{1}$ Ibid., p. 41.

${ }^{2}$ Ibid., p. 42

${ }^{3}$ Komar Andasasmita, Notaris Selayang Pandang, Cet.2, Alumni, Bandung, 1983, p. 261

${ }^{4}$ Habib Adjie, Hukum Notaris Indonesia (Tafsir Tematik Terhadap UU No. 30 Tahun 2004 Tentang Jabatan Notaris), Cet. Pertama, Refika Aditama, Bandung, 2009, p. 24

${ }^{5}$ M. Luthfan Hadi Darus, Hukum Notariat dan Tanggung Jawab Jabatan Notaris, (cetakan pertama, UII Press, 2017, Yogyakarta), pp. 38-39

${ }^{6}$ Habib Adjie, Kebatalan Dan Pembatalan Akta Notaris, (Surabaya : 2010, refika Aditama), p.19.

${ }^{7}$ Freddy Haris \& Leny Helena, Notaris Indonesia, (Jakarta : Lintas Cetak Publishig, 2017), hal.77

${ }^{8} \mathrm{http} / /$ www.pa-blitar.go.id/informasi-pengadilan/160-untuk-kepentingan-apa-batasanusia- dewasa-itu.html Diakses pada tanggal 9 januari 2020
} 
adult age limit. If the appearer is still under 18 (eighteen) years of age, then the deed that will be made by the notary will become underhanded deed, while the position of the deed is weak and does not have legal certainty. Based on the description of the age limit of appearers as above mentioned, the legal issues entitle "Legal Principle of Authentication Power of Authentic Deed Becomes Private Deed Due to Age Limit for Notary Appearers" is interesting to conduct. The title is a representation of the research problems, namely: What is the ratio legis for setting the age limit for notary appearers? What is the legal principle that underlies the gradation of authentication power of authentic deeds to private deeds due the inability to meet the age limit for notary appearers?

\section{RESEARCH METHODS}

The normative juridical method is applied in this research, meaning that it emphasizes on the normative legal science; in obtaining legal materials, this study adheres to the legal aspects contained in the law and decisions concerning marriage agreements and in relation to legal protection of creditors. The problem approaches used are: statutory approach, conceptual approach, and historical approach.

\section{RESULTS AND DISCUSSION}

\subsection{The Reatio Legis of Age Limit Regulations for Notary Appearers}

There are various provisions regarding the adult age limit in Indonesian legal regulations, which causes confusion in determining the exact age a person can be said to be mature and capable of taking legal actions. One of the legal actions requiring a person to attain the legal age limit is an application for land registration. A person who has reached a certain age or adult limit is declared competent to appear before a notary public. Regulatory pluralisms regarding legal age based on statutory regulations in Indonesia are as follows:

1. The Civil Code

According to the Civil Code, the competency element stipulated in Article 1320 of the Civil Code requires that parties as legal subjects who will make an agreement shall comply with the competency criteria according to the law, namely being mature and having the ability to carry out legal actions themselves, which means that these parties shall be able to mutually support their own rights and obligations. In Article 330 of the Civil Code, it is stated that:

"Immature means those who have not reached the age of twenty-one years, and have not entered into matrimony. If the marriage is dissolved before they are twenty-one years old, then they shall not regain the status as a minor. Minors, who are under parental authority shall be under guardianship, pursuant to and in the manner described in the 3 (third), 4 (fourth), 5 (fifth) and 6 (sixth) section of this chapter."

Based on Article 330 of the Civil Code, people who are capable of committing legal actions are those who are 21 years old or married before the age of 21 . This provision is based on quantitative and qualitative measures. This quantitative measure is based on the age or time span in which they live their lives, while the qualitative measure is determined by a person's marital status or whether a person is married or not. Thus, if a person is married before the age of 21 (twenty-one) years, he is considered an adult.

2. The 2014 Law No. 2 on Notary Public

The age limit to take legal actions or to sign an authentic deed is clearly regulated in this law, especially for appearers and a witness, which is contained in Article 39 of Law on Notary Public. It is stated that:

(1) The appearers shall meet the following requirements:

a. attaining 18 (eighteen) years of age or married; and

b. capable of doing legal actions

(2) The appearers must be recognized by the Notary or introduced to him by 2 (two) knowing witnesses attaining the minimum age of 18 (eighteen) years or married, and is capable of taking legal actions or is introduced by other 2 (two) appearers.

(3) The introduction as referred to in paragraph (2) is expressly stated in this deed. In this article, it has been explicitly explained that the minimum age for a person capable of taking legal actions to appear before a notary is 18 (eighteen) years. In addition, it also explains the minimum age limit for a person to be a witness. The law also requires a witness to be competent in carrying out legal actions. Thus, it is clear that the ability to determine the validity of an agreement is important.

3. The 1974 Law No.1 on Marriage

Article 47 paragraph (1) of the Marriage Law (hereinafter abbreviated to UUP) states: "children who have not attained the age of 18 years or have never been married are under the authority of their parents as long as their powers (parents) are not removed". According to the Marriage Law, a person is declared eligible for marriage when they reach the age of 18 years or more. A person who has not reached the age of 18 is still under the control of his parents. The ability of a person to perform legal acts is determined by whether or not the person is considered legally mature. The maturity of a person is a benchmark in determining whether or not a person is considered capable of committing a legal act. The maturity of a person refers to a condition that a person has been legally matured to be able to perform a legal action which is determined by age restrictions. Thus, legal maturity is a 
requirement to consider someone is capable to carry out all legal actions. An adult condition that meets the requirements of this law is called "maturity". An adult is capable of performing all legal acts, for example making agreements, entering into matrimony, and making wills. ${ }^{1}$

Article 6 paragraph (2) of the Marriage Law states that to enter into matrimony, a person who has not attained the age of 21 (twenty one) years must obtain the permission from both parents. Furthermore, the Law stipulates the permissibility for marriage, as stipulated in Article 7 paragraph (1) and paragraph (2), which states as follows: Article 7 (1) Marriage is permitted when the male attains the age of 19 (nineteen) years and the woman has reached the age of 16 (sixteen) years. (2) In the case of irregularities in paragraph (1) in this article, dispensation may be requested from the court or other official requested by both the male or female parents. The law stipulates the minimum age limit for a person to have a marriage. It is explicitly stated in Article 7 paragraph (1) of the Marriage Law that the conditions for a marriage for the man are 19 years old and the women 16 years old.

The Marriage Law states different provisions regarding capability to perform legal acts. For example: Article 6 paragraph (2) of the Marriage Law also determines another person's ability to enter into matrimony. The provisions of Article 6 paragraph (2) of the Marriage Law is not explicit so that it does not provide legal certainty regarding the provisions on the age of a person to get married, these provisions can be interpreted as follows: 1) To get married, if the has reached the age of 21 (twenty one) years, he/she can enter into a matrimony without first obtaining permission from both parents; 2) Marriage can be carried out by someone, if the man has reached the age of at least 19 (nineteen) years and a woman has attained the age of at least 16 (sixteen) years.

4. The Law on General Election

Article 1 no. 34 of the Law No.07 of 2017 (hereinafter written the Election Law) states: Indonesian citizen voters who are 17 (seventeen) years of age or older, is married, or have been married. ${ }^{2}$ Likewise for the election of the Regional Representative Council (hereinafter referred to as DPD), according to this law, the participants are individuals who have met the requirements, including: a. Indonesian citizens who have reached the age of 21 (twenty one) years or more; b. Fear God Almighty; c. Residing in the territory of the Republic of Indonesia; d. Able to speak, read, and/or write in Indonesian; e. Have at least high school diploma or its equivalent (madrasah aliyah, vocational high school, vocational madrasah aliyah, or other diploma of equal strata); f. faithful to Pancasila, the 1945 Constitution of the Republic of Indonesia, the Unitary State of the Republic of Indonesia, and Bhineka Tunggal Ika; g. have never been sentenced to imprisonment by a verdict of a court with a fixed legal power due to committing a criminal act punished by imprisonment of 5 (five) years or more, unless the individual openly and honestly declares to the public that the person has served as former convict; h. physically and mentally healthy and free from narcotics abuse; i. registered as voters; and J. willing to work full-time. It can be concluded that the age limit to participate in the election is 17 years or more, married, or have been married, therefore the age limit is only for the benefit of participating in the election. Meanwhile, to be nominated as a DPD member at least 21 years of age, it means that the goal is only to become a candidate for DPD member. A legal rule is promulgated based on certain purposes, therefore, it is important to not justify a statement regulating age limit legal rules are mutually diverse and contradicting.

5. The Law No.23 of 2002 on Child protection

The Article 1 paragraph (1) stated that a child is a person in the case of a naughty child has reached the age of 8 (eight) years but has not reached the age of 18 (eighteen) years and has never been married. Therefore, from the provisions of Article 1 Number 1, it only states that those who have the right to protection from the Child Protection Law are someone who have not attained the age of 18 years, thus the rules regarding the adult age limit in the Law are children who are the aim of child protection, however if he is over 18 years of age, he is treated as an adult, especially when it comes to criminal law.

6. The Law No.39 of 1999 concerning Human Rights

The Article 1 point 5 stated: Article 1 paragraph (5) that: A child is every human being who is under 18 (eighteen) years of age and has not been married, including children who are still in the womb if it is for their interests.

\section{Law No. 13 of 2003 Concerning Manpower}

Article 1 point 26 that: A child is every person who is under 18 (eighteen) years of age. This provision states that the requirements for people who can be employed as workers are those aged 18 years or over. So that if there are companies that use the services of workers who are less than 18 years old, they will be subject to sanctions.

8. The Law No. 12 of 2006 on Citizenship of the Republic of Indonesia

This law regulates requirements and ways to obtain citizenship of the Republic of Indonesia. A person shall be previously considered capable of performing legal acts. Article 9 point a stated that: request for naturalization may be forwarded by the applicant upon meeting the following requirements: a. aged 8 (eighteen) or married; in addition to the provision of Article 9 stating that the age of 18 years as the age limits of legal capability, other

\footnotetext{
${ }^{1}$ Abdulkadir Muhammad. 2010. Hukum Perdata Indonesia. Bandung : PT Citra Aditya Bakti.p. 40

${ }^{2}$ Article 1 no.34 of the Law No.07 of 2017 on General Election
} 
articles of the same Law are cohesively mentioned the age of 18 years as the legal capability limit. Thus, the objective and interest of adult age limits for labors is those who have attained the age of 18 years.

9. Compilations of Islamic Law

Article 98 paragraph (1) of the Compilation of Islamic Law explains the age limit for a person, namely: "The age limit for a child's maturity is 21 years, as long as the child is not physically or mentally disabled or has never been married." The above provisions means an adult is someone who has attained the age of 21 years or married, is not disabled or crazy, and can be responsible for him.

10. The Law No. 21 of 2007 on Elimination of Human Trafficking Crimes

The Law No.21/2007 explains the age limit for being underage. It is stated in Article 1 point 5 as follows: Article 16. A Child is a person under the age of 18 (eighteen) years old, including an unborn baby.

11. The Decree of the Minister of Home Affairs, Directorate General of Agrarian Affairs, Directtorate of Land Registration Number Dpt.7/539/7-77, That a person is called an adult in terms of:

1. Political maturity, the minimum age limit is 17 years to be able to participate in the Election;

2. Sexual maturity, the minimum age limit is 16 years for women and 19 years for men to be able to get married according to the Marriage Law;

3. Legal maturity is a certain age limit according to the law which can be considered capable of performing legal acts.

Based on several provisions in the aforementioned statutory regulations, there is still no uniformity regarding a person's adult age, some impose a limit of 21 (twenty one) years, some 18 (eighteen) years, and some even 17 (seventeen) years. .

12. The Supreme Court

The efforts to uniform the adult age limit, the Supreme Court have anticipated by:

4. Issuing Circular Number 7 of 2012 concerning the Legal Formulation of the Results of the Supreme Court Plenary Meeting as Guidelines for the Implementation of Tasks for the Court. The Supreme Court Circular has already explained the provisions regarding the limits of a person's maturity. It was stated in the results of the Civil Chamber Meeting on March 14-16, 2012, that mature means capable of performing legal acts, namely people who have attained the age of 18 years or have been married. A person's maturity is also stated in the results of the Criminal Chamber Meeting of the Supreme Court of the Republic of Indonesia. It is stated in the results of the Criminal Chamber Meeting for Special Crimes, that the limit of a person's maturity depends on the case.

13. The Circular Letter of Minister of Agrarian and National Land Agencies Number 4/SE/I/2015 on the Perimeter of Adult Age in Acquiring Land Service

In the provision number 7 , it states that the age of maturity for taking legal actions in the framework of land services is at least 18 years old or married. The National Land Agency as the provider of land services considers 175 different provisions regarding the adult age limit that the age limit to obtain services in the land sector in each region. In order to avoid confusion and to become one legal entity, the Head of the National Land Agency issues this Circular. Thus, it is expected that there will be no rejection of the application for land registration even though the applicant is under the age of 21 years old, because it has been specifically regulated in the Circular Letter Number 4/SE/I/2015.

Referring to its legal provisions, there found some conflicts among the applicable laws in Indonesia. In legal matters of the age limit for adults and the ability to carry out legal actions in a legal system, the legal principles to answer those problems are:

a. Lex specialis derogate legi generalis where special provisions override general provisions.

b. Lex pestiriori derogate legi priori where the new law overrides the old law.

In several legal provisions regarding age limits to perform legal acts, the Civil Code stipulates that in general the adult age limit is 21 (twenty one) years, but for special acts it violates the provisions of the adult age limit of 21 (twenty one) years. For, it applies the principle of the special provisions overriding the general provisions (Lex specialist derogate legi generalis). Such as the legal act of entering into matrimony, the general provisions on the age limit for adults can be deviated because of committing a legal act of committing marriage. Meanwhile, the Civil Code and Law No. 2 of 2014 concerning the Position of Notary Public have different provisions in relation to the age limit for the ability to take legal actions. Toward this difference, the principle of the new law overrides the old law (Lex Posteriori derogate legi priori) is applied.

\subsection{Legal Principle Underlying the Gradation of Authentication Power of Authentic Deeds to Private Deeds Due to the Inability to Meet the Age Limit for Notary Appearers}

The precautionary principle states that in performing the function and position, a notary is obliged to apply the principle of precautionary in order to protect the interests of the community entrusted to him. The purpose of applying the precautionary principle is in order that the notaries are always in the correct signs. With the application of the precautionary principle, it is expected that public trust is maintained in other that people are willing to use 
notary services. Any action must be taken and arranged under careful consideration. Criminal law problems in notarial practice are caused by the lack of the notary in making authentic deeds towards the data of the parties related to the subject or object brought by the parties to make an authentic deed, which causes frequent crimes such as false documents or false information committed by the parties in authentic deed made by a notary.

To perform their duties and positions, notaries shall implement the principle of precautionary in the process of making authentic deeds in regards to legal problems on authentic deeds made by notaries because there are parties committing crimes such as providing false letters and false information into the deeds made by Notary Public. In order to prevent crimes that could bring notaries into legal issues, it is necessary to re-stipulate the Law on Notary Position regarding notary guidelines and guidance to act more carefully, thoroughly and carefully in the process of making authentic deeds. Basically, a private power of attorney even though it is done with the consent of both parties does have a legal basis in accordance with the principle of freedom of contract which is known in article 1334 of the Civil Code. But from the perspective of authenticity one deed has a weakness because the private power of attorney only applies to both parties. ${ }^{1}$ However, in connection with the existence of a deed as a means of authentication, the position of the private power of attorney is very weak and has no legal certainty. In principle, a deed is a letter as a sign of evidence, which contains the events that constitute the basis for a right or engagement, which was made from the beginning on purpose for evidence or authentication. ${ }^{2}$ Thus, to be classified in the definition of a deed, the letter must be signed. Traditional signature functions as identification and statement of will.

Article 1 paragraph 1 of the Law on Notary Public Position states that a notary is a public official who has the authority to make authentic deeds and other powers as referred to in this law. An authentic deed, according to article 1868 of the Civil Code is: an authentic deed is a writing which in its form is determined by law, made by or in front of a public official having the authority for that purpose where the deed was drawn up. In the contrary to authentic deeds, under-hand writing which is freely made, as stated in Article 1874 of the Civil Code that is considered as deeds signed under hand, letters, lists, household affairs documents and other writings made without the intermediary of a public official.

The mistakes made by notaries in performing their duties cannot be separated from the existing sanctions. It can be in the form of criminal sanctions or civil sanctions. Civil applies to deeds made by a notary that lose their character as a notary deed; the deed loses its authenticity. Basically, a power of attorney under hand' private power of attorney, though it is made with the consent of both parties, does have a legal basis in accordance with the principle of freedom of contract which is known in article 1334 of the Civil Code. But from the perspective of authenticity one deed has a weakness because the private power of attorney only applies to both parties. However, if a lawsuit or intervention made by other parties, then the power under the hand will be a problem. Regarding the private power of attorney as a private deed which acts as evidence, if it is only under the handed deed, means it has a weakness for the authentication process. However, in relation to the existence of a deed as a means of evidence, the position of the private power of attorney is very weak and has no legal certainty. In principle, a deed is a letter as a sign of evidence, which contains the events that constitute the basis for a right or engagement, which was made from the beginning on purpose for authentication. To be classified as a deed, the letter must be signed. The requirement to sign a letter to become a deed stipulated in the Article 1869 the Civil Code, thus train tickets, receipts, etc., are not considered as deeds. ${ }^{3}$

Article 1869 of the Civil Code states that a deed that cannot be treated as an authentic deed, either due to the lack of authority or incompetence of the public official concerned, or because of a defect in its form, has the power to be under-hand writing/ private writing if it is signed by the parties. ${ }^{4}$ Therefore, only giving a cross is not a signature because the individualization character does not exist. ${ }^{5}$ The function of traditional signatures is identification and statement of will. Article 1874 of the Civil Code states that A private writings are deeds signed under hand/privately, letters, lists, household affairs letters and other writings that are made without the intermediary of a public official. With the signing of an underhand writing, the thumbprint is affixed with a statement dated from a notary public or other official appointed by law stating that the thumbprint is known to him or has been introduced to him, that the deed has been explained to that person, and that after that the thumbprint has been affixed in the writing before the official concerned, this officer shall prove the writing. By law, further regulations can be made regarding these statements and bookkeeping. Article 1874 point a. If the interested party wants, other than the matters referred to in the second paragraph of the previous article, the signed private writings may also be given a statement from a notary public or other official appointed by law, stating that the signer is known by him, or introduced to him, that the contents of the deed have been explained to the signatory, and that the signing is carried out before the official. In this case, the provisions of the third and fourth paragraphs of the

\footnotetext{
${ }^{1}$ Soerjono Soekanto \& Sri Mamudji, Penelitian Hukum Normatif-Suatu Tinjauan Singkat, (Jakarta : Rajawali Pers, 2001), hlm. 13

${ }^{2}$ Herlien Budiono, 2007, Kumpulan Tulisan Hukum Perdata di Bidang Kenotariatan, (Bandung :PT. Citra Aditya Bakti, 2007$)$, hlm.102.

${ }^{3}$ Soerjono Soekanto \& Sri Mamudji, Penelitian Hukum Normatif Suatu Tinjauan Singkat, (Jakarta : Rajawali Pers, 2001 ), p. 206

${ }^{4}$ Herlien Budiono, Kumpulan Tulisan Hukum Perdata di Bidang Kenotariatan, (Bandung : PT. Citra Aditya Bakti, 2007), p.220.

5 ibid.
} 
previous article apply.

Private deeds are deliberately made for authentication by the parties without assistance from officials. So it is solely made by the parties concerned. The private deed is not regulated in HIR, but the S 1867 no. 29 regulated the provision for Java and Madura, while those outside Java and Madura are regulated in Articles 286 to 305 Rbg. Included the meaning of the private letter, according to article $1 \mathrm{~S} 1867$ no. 29 (Article 1874 of the Civil Code, $286 \mathrm{Rbg}$ ) are deeds under hand, registers, and records regarding household and other documents made without the assistance of an official. ${ }^{1}$ Article 1875 of the Civil Code: An under-hand writing which is recognized by the person before him or legally deemed to have been justified by him, creates complete evidence such as an authentic deed for those who sign it. To carry out a legal action requires a statement of the will from the person doing it, namely a statement (verklaring) in accordance with his will. An agreement occurs when an agreement is reached between the parties from a statement of the will of the parties concerned. Thus, it can be concluded that in principle, the form of a statement of will, both as an offer (aanbod) and acceptance (aanvaarding) is free and can be done in various ways, both verbal and written, that can be understood and accepted by the public. ${ }^{2}$ Article 1867 of the Indonesian Criminal Code states that written evidence is carried out in authentic writing or by handwriting. Theoretically, an authentic deed is a letter or deed which from the beginning was deliberately made for authentication evidence. From the beginning, this deed is made as authentication deed. The private deed for the Judge is "Free Evidence" (VRUBewijs) because it only has the strength of material evidence after its formal strength has been proven, while the formal authentication power will only occur, if the parties concerned have known the truth of the content and method of making the deed. Thus, private deed is different from authentic deed, because if a private deed is declared fake, then those who use the underhand deed as evidence shall prove that the deed is not is valid. includes:

Based on the above description, authentic deeds and private deeds have the evidentiary value of a deed which

1. External Authentication Power

The power of external evidence means that the deed itself has the ability to prove itself to be an authentic deed; considering that since the beginning, since there was an intention from interested parties to produce evidence, it has gone through a process according to and fulfilling the provisions of Article 1868 of the Jungcto Civil Code Law Number 2 of 2014 concerning The position of Notary (or previously staablad 1860 Number 3 Reglement of Notary ambt in Indonesia), this power of evidence does not exist in the private deed/letter (Vide Article 1875 of the Civil Code).

2. Formal Authentication Power

The strength of formal evidence means the authentic deed proves what is stated in the deed is a description of the will of the parties, the will is described by or before the competent official in carrying out their duties, in the formal sense, an authentic deed guarantees the truth of:

- Date

- Signature

- Comparantes and

- Where the deed was made

The notary deed also proves the truth of what is witnessed, namely what the notary has seen, heard and experienced himself as a public official in carrying out his position, and private deed has no formal power, unless the signer of the letter/deed acknowledges the correctness of the signature.

3. Material Authentication Power

The strength of material evidence means that the deed has proven the truth of the evidence legally to everyone, who makes or orders the deed as a proof for himself or known as "Preuve Preconstituee" meaning that the deed has the material authentication power. This power of evidence in mentioned Articles 1870, 1871 and 1875 of the Civil Code. Therefore, the authentic deeds act as perfect evidence and bind the parties who made the deed. Thus, anyone who denies the validity of an authentic deed as evidence shall prove the reverse fact.

\section{CONCLUSION}

The conclusions have been drawing up in relation to the above descriptions of the research, as follows:

1. The Ratio Legis in determining the age limit for notary's appearers is an adult principle based on the law, namely the age limit which is considered capable of acting and being responsible for any legal actions. According to a psychological point of view, being adult means that each individual is able to control their emotions, while intellectually it is considered to have been able to quickly and accurately understand a situation and condition that has been faced. The Law on Notary Position states that the age of maturity is 18 (eighteen) years old or is married. At the age of 18 (eighteen) years, a person is considered competent to act so that he is

\footnotetext{
${ }^{1}$ Sudikno Mertokusumo, Hukum Acara Perdata Indonesia, (Yogyakarta : Universitas Atma Jaya Yogyajakarta, 2010), p. 218

${ }^{2}$ Ibid., pp. 215-216.
} 
able to be consciously and psychologically responsible for a legal act committed in front of a notary public.

2. The legal principle used in the gradation of the power of evidence of authentic deed to private deed due to the inability to meet the age limit for notary's appearers is the principle of legal certainty on the age limit for notary's appearers. Article 41 of the Law on the Position of Notary which refers to Article 39 clearly states that a violation of Article 41 degrades the deed to only have the power of evidence as a private deed. Notary deed is evidence that has perfect proving power, if all formal and material procedures have been fulfilled. If one of the procedures is missed, then in the process of evidence by the court, the deed is declared imperfect and the power of evidence is degraded into a private deed.

\section{SUGGESTIONS}

Based on the above analysis, the authors provide the following suggestions:

1. The notary shall be more careful and serious to perform their responsibilities in legalizing private deeds because it is possible that, applicants may not have good intentions, so that if they are negligent in legalizing the deed, it will cause serious legal problems that harm the parties involved.

2. The parties who use the services of a notary public may contribute to assisting the notary in expressing the truth based on good faith and honesty, so that the deed is perfect and in accordance with applicable legal rules, so as not to harm any party.

\section{REFERENCES}

A.A Andi Prajitno, Pengetahuan Praktis tentang apa dan siapa notaris di Indonesia, Perwira Media Nusatara, Surabaya, 2015

Abdulkadir Muhammad. 2010. Hukum Perdata Indonesia. Bandung : PT Citra Aditya Bakti

Effendi Perangin,Hukum Agraria di Indonesia, Suatu Telaah dari Sudut Pandang Praktisi Hukum,(Jakarta : Rajawali Pers, 1991)

Freddy Haris \& Leny Helena, Notaris Indonesia, (Jakarta : Lintas Cetak Publishig, 2017)

G.H.S Lumban Tobing, Peraturan Jabatan Notaris, Cetakan ke-3. (Jakarta: Erlangga,1983),

Habib Adjie, Hukum Notaris Indonesia, (Bandung : Refika Aditama, 2008)

, Hukum Notaris Indonesia (Tafsir Tematik Terhadap UU No. 30 Tahun 2004 Tentang Jabatan

Notaris), Cet. Pertama, Refika Aditama, Bandung, 2009

, Kebatalan Dan Pembatalan Akta Notaris, (Surabaya : 2010, refika Aditama)

Herlien Budiono, 2007, Kumpulan Tulisan Hukum Perdata di Bidang Kenotariatan, (Bandung :PT. Citra Aditya Bakti, 2007)

Komar Andasasmita, Notaris Selayang Pandang, Cet.2, Alumni, Bandung, 1983

Marthalena Pohan, Tanggunggugat Advocaat, Dokter, Notaris, (Surabaya: Bina Ilmu, 1985)

Marwan Effendy Kejaksaan Republik Indonesia, Posisi dan Fungsinya dari Perspektif Hukum,(Jakarta: PT. Gramedia Pustaka Utama, 2005

M. Luthfan Hadi Darus, Hukum Notariat dan Tanggung Jawab Jabatan Notaris, (cetakan pertama, UII Press, 2017, Yogyakarta)

N.G.Yudara, Pokok-pokok Pemikiran disekitar kedudukan dan fungsi notaris serta akta Notaris Menurut Sistem Hukum Indonesia, (Renvoi, Nomor.10.34.III, March 3, 2006).

Sudono. 2019. Untuk Kepentingan Apa Batasan Usia Dewasa Itu. Available from http://www.pablitar.go.id/informasi-pengadilan/160 [retrieved: January 9, 2020]

Soerjono Soekanto \& Sri Mamudji, Penelitian Hukum Normatif-Suatu Tinjauan Singkat, (Jakarta : Rajawali Pers, 2001)

Subekti, Aneka Perjanjian, Cetakan ke-10. (Bandung: PT. Citra Aditya Bakti, 1995)

Sudikno Mertokusumo, Hukum Acara Perdata Indonesia, (Yogyakarta : Universitas Atma Jaya Yogyajakarta, 2010)

W.J.S. Poerwadarminta. Kamus Umum Bahasa Indonesia, Cetakan ke-10, (Jakarta: Bala Pustaka, 1987). 